\section{Scoring goals and sharing the love for marine turtle conservation in Central America}

In a world overflowing with messages of doom and gloom it is easy to forget our capacity for positivity and the difference it can make to our motivation. There is no doubt that globally people are subject to many pressures and concerns in their day-to-day lives and these stresses share common themes across many different walks of life. In the conservation world two key and often related issues are the environment and economics. Finding creative solutions to the seemingly ever-increasing challenges is integral to conservation, and sharing and promoting the successes, rather than focusing on the negative, is often a challenge. Non-governmental organizations are constantly searching for new ways to engage communities and the wider public to foster support for conservation.

An example of the impacts of economic pressures is seen in many low-income coastal regions, where residents frequently view marine turtle eggs as an economic resource. This is reinforced by a cultural and traditional legacy in which the consumption of eggs is a social norm. Today, conservation initiatives must offer a higher economic incentive for the protection of eggs and turtles than would otherwise be received from alternate uses (even if those are illegal). This is particularly true for hawksbill eggs in El Salvador and Nicaragua; conservation legislation formed by top-down, non-participatory measures has failed to protect hawksbill nests in both countries. However, the purchase of hawksbill nests for protection is financially unsustainable and does little to foment a positive local conservation ethic.

Fauna \& Flora International (FFI) and the Eastern Pacific Hawksbill Initiative (ICAPO), two NGOs that cooperate on turtle conservation across the Eastern Pacific region of Central America, have been running an initiative in the 2012 nesting season to add non-economic values to hawksbill eggs. The Copa Carey (Hawksbill Regional Cup, http://www. hawksbill.org/hawksbillcup.html), is a friendly competition, emulating the Football World Cup, aimed at increasing interest and participation from the local communities who live around the two most important hawksbill nesting sites in the region (Estero Padre Ramos in Nicaragua, and Bahia Jiquilillo in El Salvador). Unifying the communities through healthy international competition, where the winner of the 'final match' is the team who scores the most conservation goals, awarded according to a variety of categories such as number of hawksbill nests protected and number of hatchlings released.

By presenting the 2012 turtle season to the participating communities in a new light the hope is to influence, in a positive way, perceptions and values relating to turtles and conservation activities. This initiative has drawn on the local people's love of and pride in competition (referencing football and goals) to encourage participation.
In another initiative this idea of building connections between people and nature is scaled up nationally through FFI Nicaragua's campaign against the sale and consumption of turtle eggs and products: Yo No Como Huevos de Tortuga (I Don't Eat Turtle Eggs). Its objective is to raise awareness and deter people from the illegal use and consumption of turtle eggs and products. The campaign has been running for 4 years and unites people by creating a sense of pride and passion about the uniqueness of nature in their country.

The significance of creating connections between people, nature and the environment should not be overlooked as a valuable tool to increase conservation awareness and participation. Instilling or reigniting a sense of wonder and enthusiasm, whilst building awareness for species and their habitat, is at the heart of a campaign recently launched by IUCN at Jeju (http://www.iucn.org/cec). FFI Nicaragua's Yo No Como Huevos de Tortuga campaign is one of three examples in the IUCN campaign focused on personalizing, humanizing and publicizing stories about nature and conservation. To protect nature IUCN aims to help people fall in love with it again. Communicating creatively and presenting stories that people can relate to not only raises awareness but also shift people's attitudes and behaviour to conservation, creating as IUCN says 'A love story'.

With the hawksbill nesting season not yet over, the FFI and ICAPO teams cannot fully analyse the impact the Copa Carey has had on the community's attitudes. However, Jose Urteaga, FFI Nicaragua's Country Coordinator, has noted that 'The communities have been extremely motivated since the generation of some healthy patriotic competition. Injecting creativity into the projects and positively raising the profile of the work, not only to the communities directly involved, but also nationally via the Yo No Como Huevos de Tortuga campaign is, and will continue to be, integral to the continued success of the turtle projects'.

KARINA Berg Americas and Caribbean Programme, Fauna \& Flora International, Cambridge, UK

E-mail karina.berg@fauna-flora.org

\section{Camera traps reveal man-eater's history}

Man-eating tigers have terrified and fascinated people in equal measure throughout India's history. In shikar literature various explanations have been offered for this so-called malady among tigers, and leopards, by erstwhile big-game hunters of the colonial era. Perhaps the most popular among these were the views of legendary hunter and pioneer conservationist Edward James (Jim) Corbett, who blamed injury and, more often, old age for pushing tigers to opt for easier human prey. Other hunters, naturalists and experts have espoused similar views, based mostly on anecdotal evidence. 
In August 2012 newspapers reported a tiger killing cattle in farmland and state forests outside the eastern boundary of Nagarahole Tiger Reserve in Karnataka. On 25 August the tiger attacked a woman who was grazing livestock in the vicinity, and partially consumed her. On 26 August Forest Department staff located the tiger, using domestic elephants, and tranquillized and captured it.

Using an extensive photo-database of individual tigers camera-trapped in Karnataka over the past 2 decades, Wildlife Conservation Society (WCS)-India scientists identified the captured man-eater as tiger NHT-222. This adult male was first camera-trapped on 6 May 2005, when he was 3-4 years old, in the Metikuppe Range of Nagarahole Tiger Reserve. He was subsequently camera trapped several times over 6 years and the last photo capture was on 26 December 2011 during annual camera-trap surveys carried out in collaboration with the Karnataka State Forest Department and the National Tiger Conservation Authority.

Prior to this incident the tiger had been sighted by Forest Department staff in the last week of May 2012, injured, near a waterhole in the Sunkadakatte area. It appears that the tiger, estimated to be 10-12 years old, did not recover from his injuries and was pushed to the fringe of the Reserve, where he may have resorted to whatever prey he found, including livestock, and, unfortunately, a human being. Upon tranquillization it was discovered that the tiger had a serious injury in its right forepaw and that his canines were worn out and broken. This prompted the Karnataka Forest Department to house him in Mysore Zoo. This incident highlights the value of long-term scientific data in facilitating management decisions.

Although the fate of such individual tigers attracts much sympathetic press, this misses the point: NHT-222 is a part of a process of natural loss. Nagarahole has a healthy tiger density of 10-12 individuals per $100 \mathrm{~km}^{2}$. WCS-India's longterm studies show that mortality and dispersal cause on average a $22 \%$ annual loss to tiger populations. A stable and breeding tiger population compensates for such annual losses. In relatively secure habitats such as Nagarahole, which is rich in prey, resident females are able to rear successive litters of cubs.

N. SAMBA KUMAR and PRERNA SINGH BINDRA Wildlife Conservation Society-India Program, Bangalore, India

E-mailsamba.wcs@gmail.com

\section{Tourism turf wars: debating the benefits and costs of wildlife tourism in India}

Wildlife tourism in India, especially tiger-centric tourism, has been reined in by the country's Supreme Court because the industry was becoming increasingly unsustainable and over-exploitative. On 24 July 2012, in an interim order, the Supreme Court conditionally banned tourism in the core or critical tiger habitats of all 41 tiger reserves in India in response to a Public Interest Litigation filed by activist Ajay Dubey in September 2010. In the order the Court also asked states to notify buffers for tiger reserves as mandated by law. The purpose behind the Court's temporary ban appeared to be to force states to notify buffer zones for tiger reserves and establish standards of allowable growth and best practices for tourism. The temporary ban fuelled an ongoing, acrimonious and polarized debate on whether tourism is harming or benefiting wildlife in India, and if its benefits reach local communities or the reserves. Much of the furore appears to be centered on popular tiger reserves such as Ranthambhore, Kanha and Corbett.

The debate was triggered by a report on the impacts of wildlife tourism in the popular Corbett Tiger Reserve. The report noted that ill-planned and unregulated tourism had damaged prime meadows and habitats and choked key tiger and elephant corridors. This debate must be viewed in the context that India is home to $50 \%$ of the world's surviving tiger populations. Although the country potentially has c. $250,000 \mathrm{~km}^{2}$ of tiger habitat only c. $10 \%$ of these populations, primarily those in protected wildlife reserves, are viable source populations with reasonable densities of tigers. Protecting these source populations requires concerted efforts to mitigate all threats. Although tourism is not the primary threat to tigers, unregulated and unplanned growth in tourism is intensifying pressure, especially around some reserves, and in its current form is unsustainable.

India's wildlife tourism is growing at $15 \%$ annually and tourist facilities use local resources heavily, especially water and fuelwood. Tourism has only marginally benefited local communities and the reserves themselves. Yet, this growth in tourism is also an opportunity to increase public support for tigers and wildlife conservation in India. Unfortunately, rather than focusing the discussion on how to regulate and improve existing tourism management and practices so that the public can continue to enjoy the opportunity to view wildlife, much of the debate has focused on defending high-end tiger tourism, which is restricted to a few reserves and is less relevant to the larger conservation context.

In response to the Court's directives the Ministry of Environment and Forests (MoEF) redrafted guidelines on tourism in tiger reserves, taking into consideration the views of all stakeholders. These guidelines-largely a framework for states to build their own ecotourism strategy-allows regulated, low-impact tourism in a maximum of $20 \%$ of the core or critical tiger habitat of a reserve. The new policy also seeks to encourage low-ecological footprint, budget tourism, and a flow of benefits to local communities and reserves and envisages a conservation cess to be paid by resorts. These guidelines prohibit the building of new infrastructure in core areas or in areas from which villages have been voluntarily relocated to recreate inviolate 